\title{
Suminė ir labilioji anglis dirvožemyje tręšiant šunažolę mineralinėmis trąšomis ir bioduju gamybos šalutiniu produktu
}

\section{Žygimantas Staugaitis,}

\section{Alvyra Šlepetienė,}

Vita Tilvikienè,

\section{Žydrè Kadžiulienè}

Lietuvos agrariniu ir mišku mokslu centras, Instituto al. 1, LT-58344

Akademija, Kédainiu r.

El.paštas z.staugaitis@gmail.com
Tyrimų tikslas - palyginti mineralinių ir organinių (biodujų gamybos atliekos - BIODga) trąšų, naudotų skirtingomis normomis, poveiki dirvožemio suminès ir labiliosios anglies kiekio pokyčiams. Tyrimų objektas - dirvožemis, giliau glejiškas karbonatingasis išplautžemis (Endohypogleyi-Calc(ar)ic Luvisols), kuriame auginta 'Amba' veisless paprastoji šunažolè (Dactylis glomerata L.). Laboratoriniai tyrimai atlikti 2013-2015 m. LAMMC Žemdirbystès instituto Cheminių tyrimų laboratorijoje. Eksperimento metu nustatyta, kad trę̌̌iant mineralinèmis trąšomis dirvožemio organinès anglies kiekis buvo mažesnis, palyginti su netręštu. Suminès dirvožemio organinès anglies $\left(\mathrm{C}_{\text {org. }}\right)$ kaupimasis priklausė nuo BIODga normos, o didžiausias dirvožemio organinès anglies kiekis buvo tręšiant maksimalia azoto $\left(\mathrm{N}_{450}\right)$ norma. Tyrimai parodè trę̌simo ịtaką labiliosios vandenyje tirpios anglies (C) kiekiui dirvožemyje (0-30 cm sluoksnis). Tręšimas azoto trąšomis tiek mineralinemis, tiek biodujų gamybos atliekomis lèmé santykinai didesni labiliosios $C$ kaupimąsi viršutiniame $(0-10 \mathrm{~cm})$ dirvožemio sluoksnyje negu suminess organinés anglies $\left(\mathrm{C}_{\text {org. }}\right)$. Intensyviausi dirvožemio $\mathrm{C}$ transformacijos procesai vyko viršutiniame dirvožemio sluoksnyje, keičiantis labiliosios $C$ santykinei daliai.

Raktažodžiai: dirvožemis, dirvožemio organinė anglis, labilioji anglis, šunažolè, tręšimas, biodujų gamybos atlieka, mineralinès trąšos, azotas

\section{IVADAS}

Lietuvoje ir pasaulyje vis daugiau dèmesio skiriama dirvožemiui ir gamtosaugai. Nuo dirvožemio organinių medžiagų itin priklauso dirvožemio derlingumas. Vienas iš labai svarbių dirvožemio kokybės rodiklių yra organinès anglies $\left(\mathrm{C}_{\text {org. }}\right)$ kiekis. Nuo pastarojo priklauso augalų derlingumas, mikroorganizmų veikla, maisto medžiagų prieinamumas augalams, dirvožemio struktūra ir biologinis aktyvumas. $\mathrm{C}_{\text {org. }}$ kiekio sumažejjimas gali lemti dirvožemio degradaciją, sutrikdyti dirvožemio gebejimą sulaikyti vandenị ir maisto medžiagų tiekimą augalams (Steward et al., 2007; Arlauskienè ir kt., 2009; Cotrufo et al., 2011; Marcinkonis et al., 2011; Šlepetienè et al., 2013; Jokubauskaitè ir kt., 2014).

Dirvožemis yra antras pagal dydį anglies šaltinis po vandenynų. Vien tik Europos Sąjungos dirvožemiuose sukaupta daugiau kaip $70 \mathrm{mlrd}$. tonų organinès anglies. Tai milžiniškas kiekis, palyginti su tuo, kad kiekvienais metais ES išmetama apytikriai $2 \mathrm{mlrd}$. tonų anglies (Dimas, 2008). Teisingai naudojant dirvožemí, išsaugant ar net padidinant anglies kiekị jame galima išlaikyti iškastinio kuro ištakų pusiausvyrą (Lal, 2008). 
Pastaruoju metu vis daugiau kalbama ir tyrinejama, kaip biodujų gamybos procese likusios atliekos, panaudotos žemès ūkyje, tampa organinès anglies šaltiniu ir prisideda prie dirvožemiu kokybès gerinimo. Vis daugiau dèmesio skiriama labiliajai dirvožemio angliai (Rao et al., 2013; Hamkalo et al., 2014), kuri pripažįstama kaip gero dirvožemio indikatorius (Strosser, 2010; Dinesh et al., 2015). Labiliosios anglies šaltiniai, nustatyti chemiškai frakcionuojant, pripažistami kaip jautrūs dirvožemio organinès medžiagos kokybès ir sudèties pokyčiu indikatoriai, vykstantys dèl dirvožemio naudojimo pokyčių (Landgraf et al., 2006; Šlepetiene et al., 2010). Vandenyje tirpi dirvožemio anglis - labili, ypač greitai kintanti, ji įeina ị dirvožemio mikroorganizmų lengvai skaidomus ir greitai suyrančius mažos molekulinès masès organinius junginius. Kai kuriais tyrimais nustatytas glaudus ryšys tarp tirpios $\mathrm{C}$ kiekio ir dirvožemio mikrobiologinio aktyvumo, taip pat tarp vandenyje tirpios $\mathrm{C}$ kiekio ir molio daleliu kiekio dirvožemyje - molio mineralai aktyviai sorbuoja profiliu žemyn judančius ištirpusius organinius junginius (Scaglia et al., 2009). Labiliajai, vandenyje tirpiai angliai ekstrahuoti gali būti naudojama tiek šalta, tiek karšta ištrauka. Vandenineje ištraukoje, kurioje nustatoma C, yra ivvairių cheminių junginių - angliavandenių, kitų mažo molekulinio svorio junginių bei sudètingesnių huminių medžiagu (Landgraf et al., 2006; Šlepetiene ir kt., 2007; Liaudanskienè et al., 2013). Vandenyje tirpios anglies koncentracijos priklauso nuo dirvožemio genezès, jo horizonto (sluoksnio), augmenijos (Zhang et al., 2011). Šiame straipsnyje pateikti šie vandenyje tirpios anglies duomenys: $\mathrm{O}$ horizonte - 282-403 $\mathrm{mg} \mathrm{kg}^{-1}$; A horizonte - 174$281 \mathrm{mg} \mathrm{kg}^{-1}$.

Tręšimas yra svarbus veiksnys, lemiantis augalų produktyvumą bei cheminių junginių ir dirvožemio anglies kieki dirvožemyje. Žemès ūkio augalams tręšti gali būti naudojamos îprastos mineralinès trąšos bei kitos naujos medžiagos, turinčios augalų augimui svarbių elementų. Viena iš jų - biodujų gamybos atlieka (BIODga). Nustatyta, kad tokios trąšos naudojimas padidina šunažolès derlių (Tilvikienè ir kt., 2012). Tačiau jos poveikis dirvožemio savybèms, suminès ir labiliosios anglies pokyčiams iki šiol neįvertintas.

Šių tyrimų tikslas - palyginti mineralinių ir organinių (biodujų gamybos atliekos) trąšų, naudotų skirtingomis normomis, ittaką dirvožemio suminès ir labiliosios anglies pokyčiams.

\section{TYRIMŲ METODAI IR SĄLYGOS}

\section{Tyrimų schema ir dirvožemis}

Tyrimų objektas - dirvožemis, kuriame auginta 'Amba' veislès paprastoji šunažolè (Dactylis glomerata L.) (veislè sukurta Danijos selekcijos ir sèklininkystès firmoje DLF Trifolium). Eksperimente buvo tirti 1 lenteleje pateikti variantai.

1 lentelè. Tyrimų schema, Akademija

Table 1. Experimental design, Akademija

\begin{tabular}{cc}
\hline $\begin{array}{c}\text { Variantas } \\
\text { Treatment }\end{array}$ & \\
\hline $\begin{array}{c}\text { Mineralinès trąšos } \\
\text { Mineral fertilizers }\end{array}$ & $\mathrm{N}_{180}$ \\
\cline { 2 - 2 } Biodujų gamybos atliekos & $\mathrm{N}_{360}$ \\
\cline { 2 - 2 } (BIODga) & $\mathrm{N}_{90}$ \\
\cline { 2 - 2 } Digestate & $\mathrm{N}_{180}$ \\
\cline { 2 - 2 } & $\mathrm{N}_{270}$ \\
\cline { 2 - 2 } & $\mathrm{N}_{360}$ \\
\hline
\end{tabular}

Eksperimentas ịrengtas (koordinatès - 55 24' 03.0” N 2352'08.3”E) giliau glejjiškame karbonatingame išplautžemyje (CMg-n-w-can). Dirvožemio pagrindinès agrocheminès charakteristikos eksperimento įrengimo metu: $\mathrm{pH}-6,7-7,0 ; \mathrm{N}-0,178 \%$; $\mathrm{C}_{\text {org }}-1,61-1,75 \%$; judrieji $\mathrm{K}_{2} \mathrm{O}-128-158$, $\mathrm{P}_{2} \mathrm{O}_{5}-128-158 \mathrm{mg} \mathrm{kg}^{-1}$ (Tilvikienè, 2012). Šiame eksperimente paprastosios šunažolès buvo sèjamos pakabinama sèjamąja „Fiona“, sẻklos norma - $18 \mathrm{~kg} \mathrm{ha}^{-1}$. Tręšimui mineraliniu azotu naudota amonio salietra, kuri buvo išbarstoma ant dirvos paviršiaus balandžio mèn. pradžioje, o anaerobiniu būdu suskaidyta biodujų gamybos šalutine atlieka (BIODga) išlaistoma pagal reikiamą azoto veikliosios medžiagos kieki. Tręšimui naudotos BIODga cheminè sudetis pateikta 2 lentelèje.

\section{Dirvožemio ėminių paẻmimas}

Dirvožemio èminiai cheminèms analizèms buvo paimti grąžtu 2013-2015 m. lapkričio mèn. pradžioje trejus metus iš eilès iš kiekvieno laukelio $(0-10$, $10-20,20-30 \mathrm{~cm}$ gylio) trimis pakartojimais. Laboratorijoje dirvožemio mèginiai išdžiovinti iki orasausès būklès. Išrinkus šaknis ir matomas augalų liekanas, dirvožemio méginiai susmulkinti porcelianineje grūstuveje ir persijoti per $2 \mathrm{~mm}$ sietą. Anglies tyrimams dirvožemio èminiai papildomai persijoti per $0,25 \mathrm{~mm}$ sietą. 
2 lentelè. Tręšimui naudotos bioduju gamybos atliekos cheminẻ sudètis

Table 2. Chemical composition of the digestate used for fertilization

\begin{tabular}{|c|c|c|c|c|c|c|}
\hline \multirow{3}{*}{ Metai / Year } & \multicolumn{6}{|c|}{$\begin{array}{l}\text { Cheminès sudèties rodikliai } \\
\text { Chemical composition of the digestate }\end{array}$} \\
\hline & $\mathrm{N}-\mathrm{NO}_{3}{ }^{*}$ & $\mathrm{~N}-\mathrm{NH}_{4}{ }^{*}$ & $\mathrm{SM} / \mathrm{DM}$ & $\mathrm{C}_{\text {org. }}^{*}$ & $\mathbf{N}^{*}$ & \multirow{2}{*}{$\mathrm{pH}_{\mathrm{KCl}}{ }^{*}$} \\
\hline & \multicolumn{2}{|c|}{$\mathrm{mg} \mathrm{kg}^{-1}$} & \multicolumn{3}{|c|}{$\%$} & \\
\hline 2013 & 0,007 & 0,114 & 4,56 & 2,29 & 0,547 & 7,9 \\
\hline 2014 & 0,019 & 0,720 & 5,33 & 2,67 & 0,470 & 7,9 \\
\hline 2015 & 0,022 & 0,306 & 3,82 & 1,94 & 0,290 & 7,8 \\
\hline
\end{tabular}

Pastaba: ${ }^{\star}$ - natūralioje medžiagoje.

\section{Laboratoriniai tyrimai}

Dirvožemio ir tręšimui naudotos biodujų gamybos atliekos cheminiai tyrimai atlikti Lietuvos agrarinių ir miškų mokslų centro Žemdirbystės instituto Cheminių tyrimų laboratorijoje. Dirvožemio suminès organinès anglies kiekis nustatytas naudojant Tiurino metodo modifikaciją, „šlapio“ deginimo procedūrą atliekant Nikitino pasiūlytu būdu. V. Nikitino (1999) metodu dirvožemio organinès medžiagos oksiduojamos $+160{ }^{\circ} \mathrm{C}$ deginant $30 \mathrm{~min} .100 \mathrm{ml} \mathrm{Er}-$ lenmejerio kolbose, kalio bichromato sieros rūgšties tirpale. Dirvožemio organinès anglies $\left(\mathrm{C}_{\text {org. }}\right)$ koncentracija nustatyta spektrofotometru Cary 50 (VARIAN) $590 \mathrm{~nm}$ bangos ilgyje naudojant gliukozès standartus. Vandenyje tirpios (labiliosios) anglies kiekis nustatytas tiesiogiai vandeniniuose ekstraktuose chromatografine jonų analizavimo sistema SKALAR, dirvožemio ir vandens santykiu - 1:5. Vandenyje tirpios anglies kiekis ivertintas naudojant kalio hidroftalato $\left(\mathrm{C}_{8} \mathrm{H}_{5} \mathrm{KO}_{4}\right)$ standartų seriją $\left(20,40,60,80\right.$ ir $\left.100 \mathrm{mg} \mathrm{l}^{-1}\right)$. Taip pat analizei naudoti $0,5 \mathrm{M}$ sieros rūgšties $\left(\mathrm{H}_{2} \mathrm{SO}_{4}\right)$, skaidymo (kalio persulfato $-\mathrm{K}_{2} \mathrm{~S}_{2} \mathrm{O}_{8}$ ), antiputojimo ir 2,5 $\mathrm{M}$ natrio hidroksido $(\mathrm{NaOH})$ tirpalai.

\section{Duomenų statistinis įvertinimas}

Tyrimų duomenys statistiškai įvertinti pagal Dunkano testą panaudojus $\mathrm{R}$ programą, patikimumas - $95 \%$ tikimybès lygis.

\section{TYRIMŲ REZULTATAI IR JŲ APTARIMAS}

Siekiant ịvertinti mineralinių ir organinių (BIODga) trąšų, naudotų skirtingomis normomis, itaką dirvožemiui, buvo nustatyti dirvožemio organinès ir labiliosios anglies kiekiai, taip pat pastarosios pasiskirstymas (santykinè dalis) skirtinguose dirvožemio sluoksniuose.

Atlikus dirvožemio organinès anglies tyrimus nustatyta, kad ilgamečio bandymo metu augintos daugiametès žolès (Dactylis glomerata L.) dirvožemi praturtino organine anglimi, tačiau tręšimas skirtingomis mineralinemis ir organinėmis trąšu normomis lèmé nevienodas organinès anglies akumuliacijos tendencijas (1 pav.). Didžiausi suminès organinès anglies kiekiai (2,02 \%) dirvožemyje susikaupe patręšus šunažolę didžiausia $\mathrm{N}_{450}$ biodujų gamybos atliekos norma (BIODga). Tuo

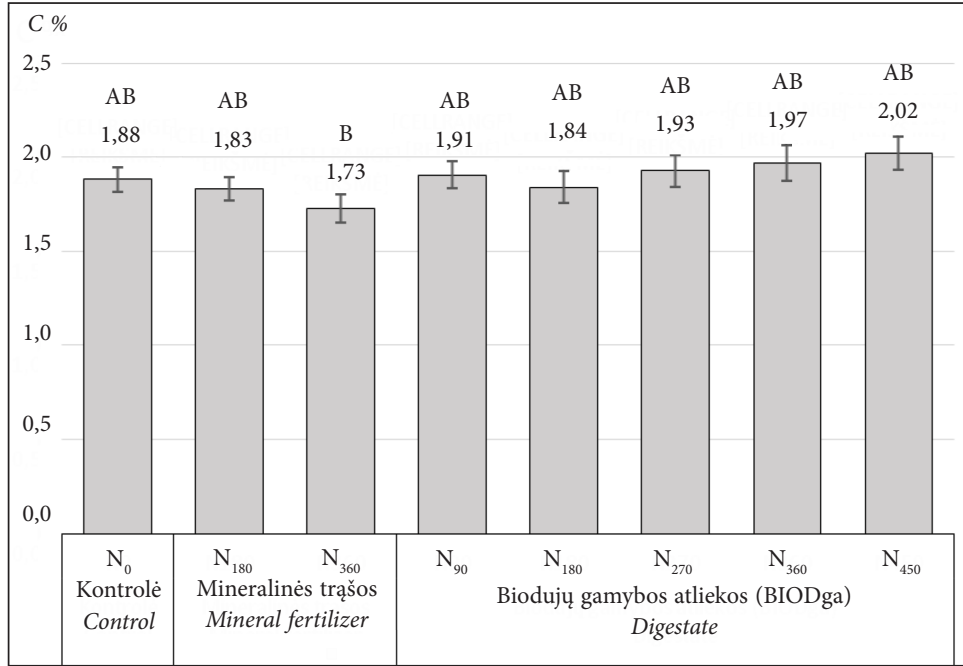

1 pav. Dirvožemio suminès organinès anglies susikaupimas $0-30 \mathrm{~cm}$ dirvožemio sluoksnyje tręšiant šunažolę mineralinèmis trąšomis ir biodujų gamybos atliekomis (2013-2015 m.)

Fig. 1. Total soil carbon accumulation in the $0-30 \mathrm{~cm}$ soil layer of Dactylis glomerata fertilized with mineral fertilizers and digestate (2013-2015)

Pastaba / Note: esminiai skirtumai tarp variantų (95\% tikimybès lygis) pažymèti skirtingomis raidemis / Values not sharing the same letter mean significant differences between treatments (at 95\% probability level). 
tarpu mineralinių azoto trąšų (amonio salietra) naudojimas didino dirvožemio organinių medžiagų mineralizacijos intensyvumą, ir mažiausi organinès anglies kiekiai (1,73\%) buvo nustatyti bandymą patręšus mineralinių trąšų $\mathrm{N}_{360}$ norma. Panašūs dèsningumai atskirais atvejais ịrodyti kitų tyrejjų, kai tręšiant organinèmis trąšomis padidejo suminès anglies kiekis (Blair et al., 2006; Šimon, 2008) naudojant tręšimui didelį mineralinių trąšų kiekị, rūgštėjo dirvožemis, sumažindamas ir organinès medžiagos kieki jame (Czarnecki et al., 2015).

Dirvožemio suminès organinès anglies kiekis $0-30 \mathrm{~cm}$ sluoksnyje atskirais metais svyravo (2 pav.). Kiekvienais metais šis rodiklis didejjo, nes auginat žolynus dirvožemyje kaupèsi organinès medžiagos. Panašios tendencijos buvo nustatytos ir atliekant kitus tyrimus (Šimon, 2008; Feizienè, 2011).
Tyrimai parodè tręšimo ịtaką labiliosios vandenyje tirpios anglies $\left(\mathrm{C}_{\mathrm{H}_{2} \mathrm{O}}\right)$ kiekiui dirvožemyje (0-30 cm sluoksnis) (3 pav.) Esminiai skirtumai buvo nustatyti tarp bandymo variantų, tręštų mineralinėmis trąšomis, atskiromis biodujų gamybos atliekos normomis (BIODga), ir kontrolès. Mažiausi labiliosios anglies kiekiai buvo aptikti ilgus metus tręšiant mineralinèmis trąšomis $\left(\mathrm{N}_{180}-0,205 \mathrm{~g} \mathrm{~kg}^{-1}\right.$ ir $\left.\mathrm{N}_{360}-0,181 \mathrm{~g} \mathrm{~kg}^{-1}\right)$. Didžiausias labiliosios anglies kiekis $\left(0,242 \mathrm{~g} \mathrm{~kg}^{-1}\right)$ dirvožemyje nustatytas tręšiant $\mathrm{N}_{450}$ BIODga norma.

Suminès ir labiliosios anglies pasiskirstymas (santykinė dalis) atskiruose dirvožemio sluoksniuose pateiktas 3 lentelèje. Didžiausi organinès anglies kiekiai susikaupè viršutiniame dirvožemio sluoksnyje - 39,2 \% netręšiant $\left(\mathrm{N}_{0}\right) ; 40,6 \%$ - tręšiant maksimalia mineralinių trąšų norma $\left(\mathrm{N}_{360}\right)$;

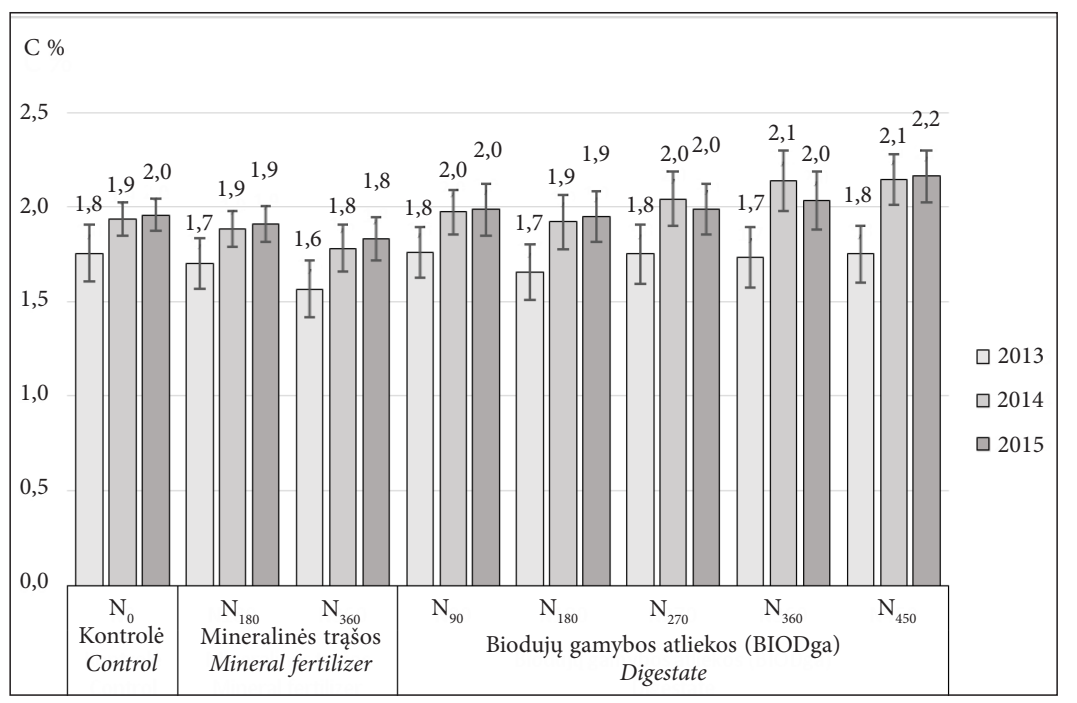

2 pav. Suminès anglies susikaupimas 0-30 cm dirvožemio sluoksnyje tręšiant šunažolę mineralinèmis trąšomis ir biodujų gamybos atliekomis (2013$2015 \mathrm{~m}$.)

Fig. 2. Total soil carbon accumulation in the $0-30 \mathrm{~cm}$ soil layer of Dactylis glomerata fertilized with mineral fertilizers and digestate (2013-2015)

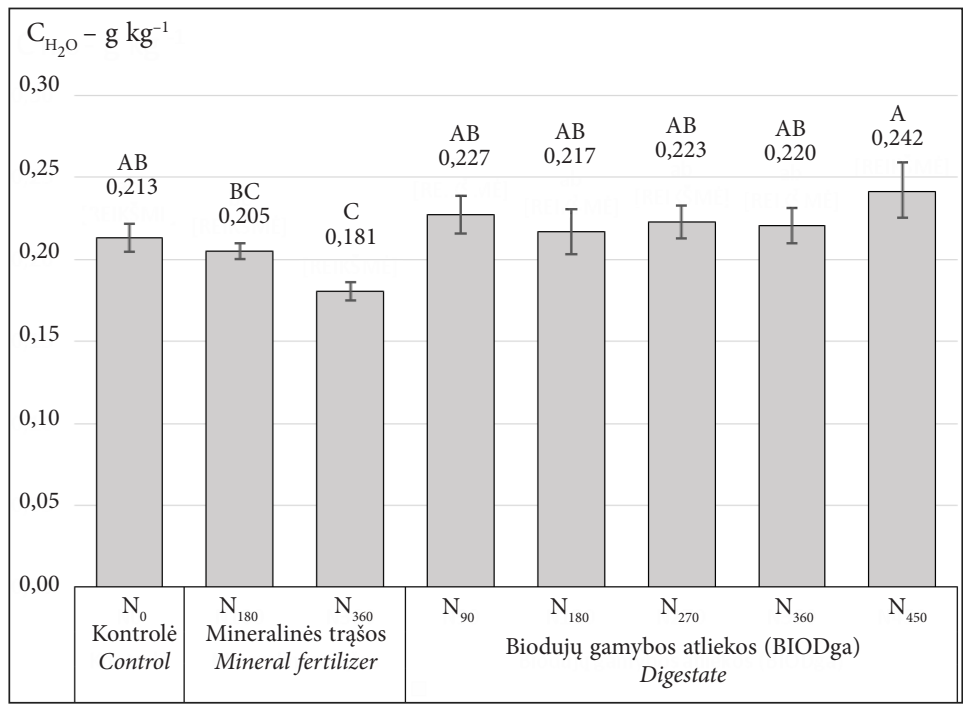

3 pav. Dirvožemio labilioji anglis $0-30 \mathrm{~cm}$ sluoksnyje tręšiant mineralinèmis trąšomis ir biodujų gamybos atliekomis (2013$2015 \mathrm{~m}$.)

Fig. 3. Labile soil carbon accumulation in the 0-30 cm soil layer of Dactylis glomerata fertilized with mineral fertilizers and digestate (2013-2015)

Pastaba / Note: esminiai skirtumai tarp variantų ( $95 \%$ tikimybès lygis) pažymèti skirtingomis raidemis / Values not sharing the same letter mean significant differences between treatments (at 95\% probability level). 
3 le nt elè. Labiliosios anglies dalis (\%) nuo bendrosios organinės anglies kiekio (0-30 cm sluoksnis). Akademija, 2013-2015 m. vid. duomenys

Table 3. Share of labile carbon (\%) from $C_{\text {org. }}(0-30 \mathrm{~cm}$ layer). Akademija, average data of 2013-2015

\begin{tabular}{cccc}
\hline Variantas / Treatment & & $\begin{array}{c}\text { Santykiné labiliosios anglies dalis (\%) nuo } \mathrm{C}_{\text {org. }} \\
\text { Relative share of labile carbon (\%) from } C_{\text {org. }}\end{array}$ \\
\hline Kontrolè / Control & $\mathrm{N}_{0}$ & 1,13 \\
\hline \multirow{2}{*}{\begin{tabular}{c} 
Mineralinès trąšos / Mineral fertilizers \\
\cline { 2 - 3 }
\end{tabular}} & $\mathrm{N}_{180}$ & 1,11 \\
\cline { 2 - 3 } & $\mathrm{N}_{360}$ & 1,04 \\
\hline \multirow{2}{*}{$\begin{array}{c}\text { Biodujų gamybos atliekos (BIODga) } \\
\text { Digestate }\end{array}$} & $\mathrm{N}_{90}$ & 1,19 \\
\cline { 2 - 3 } & $\mathrm{N}_{180}$ & 1,18 \\
\cline { 2 - 3 } & $\mathrm{N}_{270}$ & 1,16 \\
\cline { 2 - 3 } & $\mathrm{N}_{360}$ & 1,12 \\
\cline { 2 - 3 } & $\mathrm{N}_{450}$ & 1,19 \\
\hline
\end{tabular}

$42,2 \%$ - tręšiant BIODga $\left(\mathrm{N}_{360}\right)$. Mažiausi organinès anglies kiekiai nustatyti giliausiame (20$30 \mathrm{~cm}$ ) dirvožemio sluoksnyje - 27,3 \% netręšiant $\left(\mathrm{N}_{0}\right) ; 24,2 \%$ - tręšiant mineralinių trąšų norma $\left(\mathrm{N}_{360}\right) ; 24,4 \%$ - tręšiant BIODga $\left(\mathrm{N}_{360}\right)$.

Labiliosios anglies kiekio santykinis pasiskirstymas dirvožemio sluoksniuose buvo kiek kitoks, palyginti su suminès organinès anglies kiekiu. Labiliosios $\mathrm{C}$ santykinè dalis viršutiniame dirvožemio sluoksnyje buvo $39,6 \%\left(\mathrm{~N}_{0}\right) ; 37,2 \%$ tręšiant maksimalia mineralinių trąšų norma $\left(\mathrm{N}_{360}\right)$; pati didžiausia - 41,5\% tręšiant BIODga $\left(\mathrm{N}_{450}\right)$. Gilesniuose sluoksniuose labiliosios anglies kiekiai mažèjo ir buvo mažiausi giliausiame dirvožemio

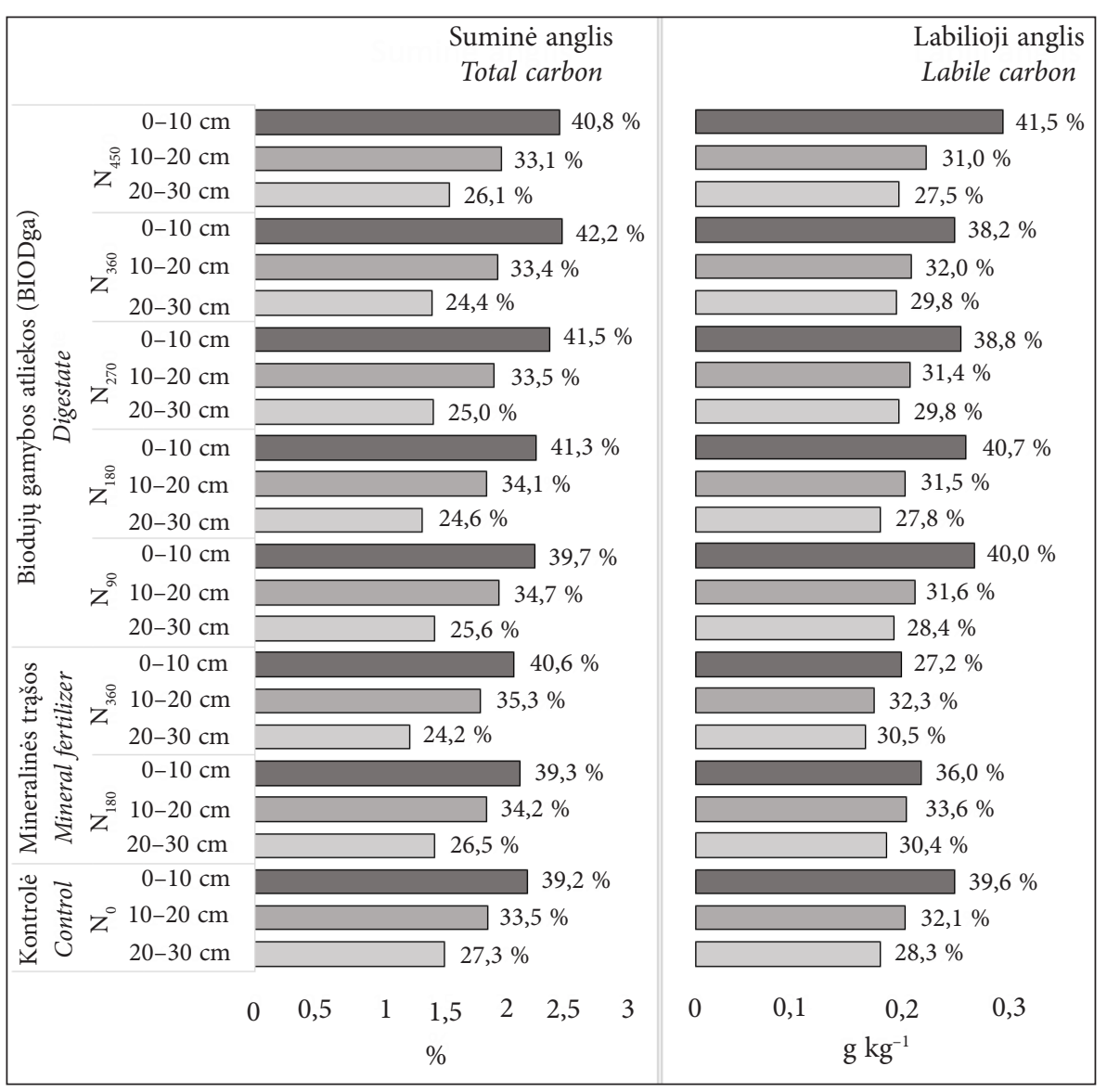

4 pav. Dirvožemio suminès ir labiliosios anglies koncentracija ir santykinis pasiskirstymas dirvožemio sluoksniuose (2013-2015 m. vid. duomenys)

Fig. 4. Total soil and labile soil carbon concentration and distribution in soil layers. Average data of 2013-2015 
sluoksnyje - 28,3\% $\left(\mathrm{N}_{0}\right) ; 30,4 \%$ tręšiant mineralinių trąšų norma $\left(\mathrm{N}_{180}\right) ; 27,5$ \% tręšiant BIODga $\left(\mathrm{N}_{450}\right)$ (4 pav.).

Taigi tręšiant mineralinėmis azoto trąšomis (amonio salietra) labiliosios anglies pasiskirstymas atskiruose dirvožemio sluoksniuose buvo tolygiausias, o tarp viršutinio ir giliausio sluoksnio pakito mažiausiai - 16,5 \%. Tuo tarpu tręšiant BIODga labiliosios anglies kiekis tarp paviršinio ir giliausio sluoksnio vidutiniškai sumažèjo $27,9 \%$; didžiausias skirtumas (33,8 \%) buvo nustatytas patręšus didžiausia BIODga $\left(\mathrm{N}_{450}\right)$ norma. Tai įrodo, kad intensyviausi dirvožemio $\mathrm{C}$ transformacijos procesai vyko viršutiniame dirvožemio sluoksnyje, keičiantis labiliosios C santykinei daliai.

Eksperimento metu nustatyta, kad santykinè labiliosios anglies dalis nuo bendrosios anglies kiekio dirvožemyje (0-30 cm sluoksnyje) nebuvo ženkli (1,04-1,19\%), tačiau priklausomai nuo dirvožemio sluoksnio bei tręšimo skyrèsi (3 lentelè). Mažiausia - 1,04 \% tręšiant mineralinèmis trąšomis $\left(\mathrm{N}_{360}\right)$; didžiausia $-1,19 \%$ tręšiant BIODga $\left(\mathrm{N}_{450}\right)$.

\section{IŠVADOS}

1. Tręšiant šunažolę mineralinėmis trąšomis dirvožemio organinès anglies kiekis buvo mažesnis, palyginti su netręštu ir tręštu BIODga. Didžiausias dirvožemio organinès anglies kiekis buvo tręšiant maksimalia biodujų gamybos atliekų norma, jos kaupimasis priklausė nuo šių trąšų normos.

2. Didžiausi labiliosios anglies kiekiai dirvožemyje buvo bandymo laukeliuose, patręštuose BIODga. Mažiausi kiekiai nustatyti tręšiant mineralinèmis trąšomis.

3. Intensyviausi dirvožemio anglies transformacijos procesai vyko viršutiniame $(0-10 \mathrm{~cm})$ sluoksnyje, ypač dideli labiliosios kiekiai nustatyti BIODga $\left(\mathrm{N}_{450}\right)$ tręšimo variante, tai ir lèmé didžiausią $\mathrm{C}_{\text {org. }}$ akumuliaciją atskirais metais.

\section{PADE்KA}

Autoriai dèkoja projektui VP1-3.1-ŠMM-01-V-03002 BIOMEDOKT už finansinę paramą.

Gauta 20160731

Priimta 20160919

\section{LITERATŪRA}

1. Arlauskienè A., Maikštėnienè S. 2009. Dirvožemio organinès anglies pokyčiai Šiaurès Lietuvoje intensyviose žemdirbystès sistemose. Ekonomika ir vadyba: aktualijos ir perspektyvos. T. 3(16). P. 132-138.
2. Blair N., Faulkner R. D., Till A. R., Körschens M., Schulz E. 2006. Long-term management impacts on soil $\mathrm{C}, \mathrm{N}$ and physical fertility. Part II. Bad Lauchstadt static and extreme FYM experiments. Soil and Tillage Research. Vol. 91. P. 39-47.

3. Cotrufo M. F., Conant R. T., Paustian K. 2011. Soil organic matter dynamics: land use, management and global change. Plant and Soil. Vol. 338. P. 1-3.

4. Czarnecki S., Düring R. A. 2015. Influence of longterm mineral fertilization on metal contents and properties of soil samples taken from different locations in Hesse, Germany. Soil. Vol. 1. P. 23-33.

5. Dimas S. 2008. Key Note Address. Climate Change - Can Soil Make a Difference? Conference Proceedings. Brussels: European Commission. P. 3.

6. Dinesh K. B., Kiranvir B., Amardeep S. T., Shivani S. 2015. Sensitivity of labile soil organic carbon pools to long-term fertilizer, straw and manure. Management in rice-wheat system. Pedosphere. Vol. 25(4). P. 534-545.

7. Feiziene D., Feiza F., Slepetiene A., Liaudanskiene I., et al. 2011. Long-term influence of tillage and net carbon dioxide exchange rate on two soils with different textures. Journal of Environmental Quality. Vol. 40. P. 1787-1796.

8. Jokubauskaitė I., Šlepetienė A., Karčauskienè D. 2014. Organinè anglis ir kiti svarbūs makroelementai rūgščiame ir kalkintame dirvožemyje. Žemés ūkio mokslai. T. 21. Nr. 3. P. 133-141.

9. Hamkalo Z., Bedernichek T. 2014. Total, cold and hot water extractable organic carbon in soil profile: impact of land-use change. ŽemdirbystèAgriculture. Vol. 101. No. 2. P. 125-132.

10. Lal R. 2008. The Role of Soil Organic Matter in the Global Carbon Cycle. Climate Change - Can Soil Make a Difference? Conference Proceedings. Brussels: European Commission. P. 64.

11. Landgraf D., Leinweber P., Makeschin F. 2006. Cold and hot water extractable organic matter as indicators of litter decomposition in forest soils. Journal of Plant Nutrition and Soil Science. Vol. 169. Issue 1. P. 76-82.

12. Liaudanskiene I., Šlepetienė A., Šlepetys J. 2013. Distribution of organic carbon in humic and granulodensimetric fractions of soil as influenced by tillage and crop rotation. Estonian Journal of Ecology. Vol. 62. P. 1-17.

13. Marcinkonis S., Booth C. A., Fullen M. A., Tripolskaja L. 2011. Soil acidity indices in East Lithuania. Communications in Soil Science and Plant Analysis. Vol. 42(13). P. 1565-1580.

14. Nikitin B. A. 1999. A method for soil humus determination. Agricultural Chemistry. Vol. 3. P. 156158 (in Russian).

15. Rao M. P., Katkar R. N., Jayalakshmi M., Rao B. S. 2013. Influence of long term fertilization on labile carbon and $\mathrm{N}$ mineralization of soil in Sorghumwheat cropping system. International Journal of 
Applied Biology and Pharmaceutical Technology. Vol. 4. P. 420-423.

16. Scaglia B., Adani F. 2009. Biodegradability of soil water soluble organic carbon extracted from seven different soils. Journal of Environmental Sciences. Vol. 21. P. 641-646.

17. Steward C. E., Paustian K., Conant R. T., Plante A. F., Six J. 2007. Soil carbon saturation: concept, evidence, evaluation. Biogeochemistry. Vol. 86. P. 19-31.

18. Strosser E. 2010. Methods for determination of labile soil organic matter: An overview. Journal of Agrobiology. Vol. 27(2). P. 49-60.

19. Šimon T. 2008. The influence of long-term organic and mineral fertilization on soil organic matter. Soil and Water Research. Vol. 3(2). P. 41-51.

20. Šlepetienė A., Liaudanskienė I., Šlepetys J., Stukonis V., Jokūbauskaitė I. 2013. Soil carbon, nitrogen and phosphorus distribution in grassland systems, important for landscape and environment. Journal of Environmental Engineering and Landscape Management. Vol. 21(4). P. 263-272.

21. Šlepetienė A., Šlepetys J., Kavoliutė F., Liaudanskienė I., Kadžiulienė Ž. 2007. Anglies, azoto, fosforo ir sieros pokyčiai Vakarų Žemaitijos natūraliose bei ívairiose agrarinèse žemènaudose. Žemdirbyste. T. 93. Nr. 3. P. 90-99.

22. Šlepetienè A., Šlepetys J., Liaudanskienè I. 2010. Chemical composition of differently used Terric Histosol. Žemdirbystė-Agriculture. Vol. 97(2). P. 25-32.

23. Tilvikienė V., Venslauskas K., Navickas K., Župerka V., Dabkevičius Z., Kadžiulienè Ž. 2012. The biomass and biogas productivity of perennial grasses. Žemdirbysté-Agriculture. Vol. 99(1). P. 17-22.

24. Zhang M. Z. X., Liang W. J., Jiang Y., Dai G. H., Wang X. G., Han S. J. 2011. Distribution of soil organic carbon fractions along the altitudinal gradient in Changbai Mountain, China. Pedosphere. Vol. 21(5). P. 615-620.

\section{Žygimantas Staugaitis, Alvyra Šlepetienė, Vita Tilvikienė, Žydrè Kadžiulienė}

\section{THE INFLUENCE OF COCKSFOOT FERTILI- ZATION WITH MINERAL FERTILIZERS AND DIGESTATE ON TOTAL AND LABILE CARBON IN THE SOIL}

\section{Sum mary}

The aim of the current research was to evaluate the impact of different rates of mineral and organic (digestate BIODga) fertilizers on the changes in total and labile carbon in the soil. The soil under study is Endohypogleyic Calcaric Luvisol in which the cocksfoot (Dactylis glomerata) variety 'Amba' was grown. Laboratory analyses were carried out in the Chemical Research Laboratory, Agricultural Institute of LAMMC, during 2013-2015. The experimental findings suggested that the soil organic carbon (Corg) content was lower in the treatments that had received mineral fertilization compared to the untreated ones. The content of Corg depended on the rate of BIODga. The highest Corg concentration was established in the treatments fertilized with the highest digestate rate $\left(\mathrm{N}_{450}\right)$. The study showed the influence of fertilization on the labile water-soluble carbon content in the soil $(0-30 \mathrm{~cm}$ layer). Nitrogen nutrition both from mineral fertilizers and digestate resulted in a relatively higher labile $\mathrm{C}$ accumulation in the upper $(0-10 \mathrm{~cm})$ soil layer compared with the total $\mathrm{C}_{\text {org }}$. With the changes in the relative share of labile $\mathrm{C}$, the most intensive soil $\mathrm{C}$ transformation processes occurred in the upper soil layer.

Keywords: soil, soil organic carbon, labile carbon, cocksfoot, fertilizing, digestate, mineral fertilizers, nitrogen 